JPKM : Jurnal Pengabdian Kesehatan Masyarakat
http://ejurnal.ung.ac.id/index.php/jpkm/index
https://doi.org/10.37905/.v1i1.7286
E-ISSN 2774-3519

\title{
PEMBERDAYAAN MASYARAKAT MELALUI PEMBENTUKAN KELOMPOK WARGA PERDULI AIDS (WPA) BERBASIS KEARIFAN LOCAL
}

\section{COMMUNITY EMPOWERMENT THROUGH THE FORMATION OF AIDS CONCERNED CITIZENS (WPA) GROUPS BASED ON LOCAL WISDOM}

\author{
Irwan, ${ }^{1}$ Nur Ayini S.Lalu ${ }^{2}$ \\ 1,2 Jurusan Kesehatan Masyarakat, FOK UNG, Gorontalo, Indonesia \\ e-mail:irwan@ung.ac.id
}

\begin{abstract}
Abstrak
Acquired Immuno Deficiency Syndrome (AIDS) adalah sekumpulan gejala dan infeksi yang terkait dengan menurunnya sistem kekebalan tubuh manusia yang disebabkan oleh virus HIV. Kearifan local masyarakat setidaknya menjadi spirit bagi para pengidap..Tujuan kegiatan ini adalah untuk melakukan pemberdayaan masyarakat dalam pencegahan HIV/AIDS melalui Pembentukkan Warga Peduli AIDS (WPA). Metode kegiatan melalui pelatihan dan Focus Group Discission (FGD) yang melibatkan masyarakat dan remaja. Kelompok masyarakat yang tergabung dalam WPA terdiri dari berbagai komponen dalam suatu lingkungan masyarakat. Hasil kegiatan sebanyak dua kelompok WPA telah terbentuk di tingkat desa Leboto yang terdiri atas 30 orang pengurus dari berbagai unsur, mulai dari tokoh masyarakat, aparat desa leboto, dan remaja. Hasil kegiatan pelatiahan dan FGD telah dilatih sebanyak 60 pengurus WPA di Desa Leboto. Kesimpulan Pemberdayaan masyarakat melalui pembentukan WPA dapat mencegah penularan HIV/AIDS pada remaja

Kata Kunci : pemberdayaan Masyarakat; HIV/AIDS; Remaja.
\end{abstract}

\section{Abstract}

Acquired Immuno Deficiency Syndrome (AIDS) is a collection of symptoms and infections associated with the decline in the human immune system caused by the HIV virus. The local wisdom of the community at least becomes a spirit for people with HIV/AIDS. The method of activity is through training and Focus Group Discission (FGD) involving the community and youth. Community groups who are members of the WPA consist of various components in a community environment. As a result of the activity, two WPA groups were formed at the Leboto village level consisting of 30 administrators from various elements, ranging from community leaders, Leboto village officials, and youth. The results of the training and FGD activities have been 
trained as many as 60 WPA administrators in Leboto Village. Conclusion Community empowerment through the establishment of WPA can prevent the transmission of HIV/AIDS in adolescents.

Keywords: Community Empowerment; HIV/AIDS; Adolescents.

(C) 2020 Universitas Negeri Gorontalo Under the license CC BY-SA 4.0

\section{PENDAHULUAN}

AIDS atau Acquired Immune Deficiency Syndrome adalah sekumpulan gejala penyakit karena turunnya kekebalan tubuh yang disebabkan oleh HIV (Kemenkes RI, 2015). Acquired Immuno Deficiency Syndrome (AIDS) adalah sekumpulan gejala dan infeksi yang terkait dengan menurunnya sistem kekebalan tubuh manusia yang disebabkan oleh virus HIV (KPA, 2010). Disebut "acquired" (diperoleh) karena hanya menderita kalau terinfeksi HIV dari orang lain yang sudah terinfeksi. "Immunodeficiency" berarti menyebabkan rusaknya sistem kekebalan tubuh (1).
Prevalensi HIV/AIDS di seluruh dunia terus mengalami peningkatan. Berdasarkan United Nations Programme on HIV/AIDS (UNAIDS) Global Statistics (2015), bahwa prevalensi HIV/AIDS di dunia mencapai 36,9 juta penderita. Pada akhir tahun 2014 tercatat penderita baru sebanyak 2 juta penderita. Dan di akhir tahun 2014 sebanyak 1,2 orang meninggal karena AIDS. Pada tahun 2014 terdapat 35 juta penderita. Penderita terbanyak berada di wilayah Afrika sebanyak 24,7 juta penderita. Sedangkan di Asia tercatat 4,8 juta penderita HIV/AIDS. Asia diperkirakan memiliki laju infeksi HIV tertinggi di dunia. Menurut 
laporan WHO dan UNAIDS, ketiga negara yang memiliki laju infeksi HIV tertinggi di dunia adalah China, India, dan Indonesia. Ketiga negara itu memiliki populasi penduduk terbesar di dunia (2) (3).

HIV/AIDS pertama kali dilaporkan di Indonesia pada tahun 1987. Sejak tahun 1987 sampai dengan tahun 2014, HIV/AIDS tersebar di 386 $(77,5 \%)$ dari 498 kabupaten/kota di seluruh provinsi di Indonesia. Jumlah kumulatif kasus HIV yang ditemukan sampai dengan tahun 2014 sebesar 160.138 kasus, sedangkan jumlah kumulatif penderita AIDS sebanyak 65.790 orang. Kasus HIV yang baru ditemukan pada tahun 2014 sebesar 32.711 kasus, sedangkan penderita AIDS sebanyak 5.494 orang (4) (5).
Kasus HIV terbesar setiap tahun ditemukan pada kelompok umur produktif yaitu 25-49 tahun dan faktor resiko terbesar dari penderita AIDS yang ditemukan dari tahun 2010 hingga 2014 secara konsisten adalah heteroseksual. (Ditjen $\mathrm{PP} \& \mathrm{PL}$ Kementerian Kesehatan RI, 2015). Epidemi HIV/AIDS juga menjadi masalah di Indonesia yang merupakan Negara urutan ke -5 paling berisiko HIV/IADS di asia (kemenkes, 2013). Laporan kasus baru HIV meningkat setiap tahunnya sejak pertama kali di laporkan (tahun 1987) (6) (7).

Lonjakkan peningkatan paling banyak adalah pada tahun 2016 dibandingkan dengan tahun 2015, yaitu sebesar 10.315 kasus. Berikut adalah jumlah kasus HIV/AIDS yang bersumber dari Ditjen Pencegahan dan 
Penanggulangan penyakit (P2P), data laporan tahun 2017 yang bersumber dari system informasi HIV/AIDS dan IM (SIHA). Berdasarkan data dari direktorat Jenderal Pencegahan dan Penanggulangan Penyakit (Ditjen P2P), data laporan tahun 2017 yang bersumber dari system informasi HIV-AIDS dan IMS (Infeksi Menular Seksual) (SIHA). Persentase HIV yang dilaporkan pada bulan OktoberDesember 2017 (triwulan 4), sebanyak $62 \%$ kasus HIV yang dilaporkan adalah laki-laki. berdasarkan jumlah kasus AIDS yang dilaporkan per provinsi tahun 2017 di Indonesia, Provinsi Gorontalo terdapat 61 kasus AIDS (8) (9).

Berdasarkan hasil validasi data Kasus HIV AIDS di Provinsi Gorontalo, periode Maret 2019 temuan kasus HIV Aids sudah mencapai 494 kasus. Dari jumlah kasus yang ditemukan, siswa dan mahasiswa menduduki urutan pertama dengan jumlah penemuan kasus tertinggi yang mencapai 61 penemuan kasus. Bahkan jika di klasifikasikan berdasarkan umur, usia $15-24$ tahun menjadi yang tertinggi .

Berdasarkan temuan dan data validasi yang dilakukan Seksi Pencegahan dan Pengendalian Penyakit Menular (P2PM) Dinas Kesehatan (Dinkes) Provinsi Gorontalo mengalami peningkatan. Data tahun 2019 yang sudah divalidasi Dinkes Provinsi Gorontalo ada sebanyak 521 orang dengan HIV/AIDS (ODHA). Kepala Dinkes Provinsi Gorontalo, Misranda Nalole mengatakan bahwa kasus HIV/AIDS terus mengalami peningkatan. Tahun sebelumnya ada 459 ODHA. Berdasarkan data dari tahun 2001 sampai 2019, jumlah 
penderita HIV terdiri dari 250 orang dan AIDS ada sebanyak 271 orang, maka total distribusi HIV/AIDS berdasarkan tahun diagnosa mencapai 521".

Dalam menanggulangi permasalahan HIV dan AIDS ada hal yang tidak kalah pentingnya yaitu semangat kebersamaan dan gotong royong yang disimbolkan dalam bahasa lokal "huyula.simbol bahasa ini syarat dengan makna saling membantu agar terindar dari masalah HIV dan AIDS. Simbol ini juga mengandung makna kerelaaan anggota masyarakat memberi pertolongan dan bantuan serta dukungan bagi mereka yang sudah berada dalam status HIV positif (ODHA).

Pengidap HIV dan AIDS secara factual mengalami keterpurukkan diberbagai segmentasi kehidupan yang membutuhkan pertolongan dan uluran tangan orang lain agar mereka dapat menjalani kehidupan social secara produktif, bukan sebaliknya, mengalami fenomena double borden; sudah menderita secara medic, dapat pula penderitaan akibat perlakuan social dari masyarakat. Kearifan local masyarakat setidaknya menjadi spirit bagi para pengidap, aktivitas , dan anggota masyarakat lainnya untuk menghentikkan penularan HIVditengah-tengah masyarakat.

Warga Peduli AIDS (WPA) merupakan salah satu upaya pencegahan dan penanggulangan HIV/AIDS yang melibatkan partisipasi masyarakat. Kelompok masyarakat yang tergabung dalam WPA terdiri dari berbagai komponen dalam suatu lingkungan masyarakat baik di tingkat Desa, Kelurahan, Rukun 
Warga (RW), Dusun, Blok dan tingkatan sejenis. Pembentukan WPA diatur dalam Peraturan Menteri Kesehatan Republik Indonesia Nomor 21 Tahun 2013 tentang Penanggulangan HIV dan AIDS, Bab XI pasal 51 ayat 1 (d) yang berbunyi "Masyarakat dapat berperan serta dalam upaya penanggulangan HIV/AIDS dengan cara membentuk dan mengembangkan WPA"

Peran utama WPA yaitu menggerakan masyarakat untuk ikut serta terlibat secara langsung dalam upaya pencegahan dan penanggulan HIV Aids. WPA diperlukan untuk mempercepat penanggulangan HIV Aids harus dilaksanakan secara terpadu dalam program pemberdayaan masyarakat dengan harapan masyarakat akan tahu, mampu, dan mau berpartisipasi dalam penanggulangan HIV Aids dilingkungannya. Selain itu masalah HIV Aids ternyata tidak hanya di bidang medis tetapi juga menyangkut faktor - factor social kemasyarakatan termasuk nilai - nilai yang berkembang di masyarakat, yang paling esensial adalah bahwa aktivitas yang berhubungan dengan HIV Aids berada dalam lingkungan masyarakat.

Oleh karena pentingnya Pemberdayaan kader WPA yang bertujuan untuk meningkatkan pengetahuan dan pencegahan perilaku beresiko dalam masyarakat. Maka diadakan pembentukan kader WPA didesa Leboto Kecamatan Kwandang Kabupaten Gorontalo Utara yang dilakukan oleh mahasiswa KKS Periode II Universitas Negeri Gorontalo. Tujuan dilaksanakannya pegabdian ini yaitu untuk menjalankan 
pemberdayaan

masyarakat melalui pembentukkan kelompok warga peduli AIDS (WPA) Berbasis Kearifan Lokal di Desa Leboto Kec. Kwandang Kab. Gorontalo Utara

\section{METODE PELAKSANAAN}

Metode yang digunakan dalam program pengabdian masyarakat ini berupa penyuluhan. Dilakukan dengan teknis sosialisasi dan penyampaian materi yang mudah di terima oleh kalangan pelajar. Selain itu dilakukan dengan menelaah sumber pustaka dan dokumen terkait berupa jurnal, buku-buku atau laporan penelitian lainnya

\section{HASIL DAN PEMBAHASAN}

Pengorganisasian program kerja utama oleh peserta KKS Pengabdian Universitas Negeri Gorontalo semester ganjil 2019 yakni dengan melakukan penyusunan kepanitiaan dan pembagian tanggung jawab masing-masing dalam melaksanakan kegiatan yang akan diselenggarakan oleh peserta KKS bekerja sama dengan perangkat-perangkat desa dan masyarakat.

Program kerja peserta KKS Pengabdian Universitas Negeri Gorontalo semester ganjil2019 di Desa Leboto, Kecamatan Kwandang, Kabupaten Gorontalo Utara terdiri atas program kerja inti dan program kerja tambahan.

\section{Program Kerja Inti}

Pengorganisasian

program kerja inti dilakukan dengan penyusunan bidang yang bertanggung jawab dalam setiap sub program yaitu sosialisasi dan pengkaderan "Warga Peduli Aids (WPA)". Teknis pengorganisasiannya yakni dengan membentuk dan membagi tugas dan tanggung jawab pada setiap bidang dalam mempersiapkan materi dan 
pemateri yang berhubungan dengan HIV Aids serta persiapan pelaksanaan sosialisasi dan pengkaderan.

Program Kerja Tambahan

Program kerja tambahan, yakni lebih khusus pada kegiatan yang dalam ruang lingkup Desa Leboto. Dalam program kerja tambahan tersebut oleh peserta KKSPengabdian Universitas Negeri Gorontalo Semester Ganjil 2019 merancang beberapa rangkaian program/kegiatan dengan melibatkan Rema Muda sebagai kepanitiaan dalam program kerja tambahan tersebut yang bekerja sama dengan mahasiswa dalam menyukseskan beberapa rangkaian kegiatan yang telah direncanakan bersama.

\section{Implementasi Program Kerja} Implementasi Program Kerja Mahasiswa KKS UNG Semester Ganji tahun 2019 yang terdiri atas program kerja inti dan program kerja tambahan antara lain:

Program Kerja Inti Implementasi program kerja inti pada masyarakat di Desa Leboto, tentang "Pengkaderan Warga Perduli Aids (WPA)" mengarah pada peningkatkan pengetahuan, penanggulangan dan pencegahan HIV Aids di desa Leboto melalui Pengkaderan Warga Perduli Aids (WPA) sehingga kader WPA dapat mengimplementasikannya kepada masyarakat di desa Leboto.

Program Kerja Tambahan

Implementasi program kerja tambahan pada masyarakat Desa Tolango bertujuan untuk menjalin tali silaturahmi antara mahasiswa dengan masyarakat maupun antar rema muda Desa Tolango. 
Pengawasan Program Kerja

Pengawasan program

kerja peserta KKS Desa Leboto di lakukan dengan cara bekerjasama

dengan

Pemerintah Desa Leboto, Kecamatan Kwandang, Kabupaten Gorontalo Utara. Peserta KKS Desa Leboto juga memiliki kordinator lapangan yang bertugas mengawasi jalannya program kerja utama maupun program kerja tambahan. Peserta KKS juga didukung oleh seluruh masyarakat Desa Leboto, Kecamatan Kwandang, Kabupaten Gorontalo Utara untuk menerima masukan dan ide terkait denganapa yang akan dilaksanakan lagi kedepan nya demi kesejahteraan hidup bermasyarakat, sosial, agama dan budaya.

\section{Evaluasi Program Kerja}

Pengevaluasian program kerja dilakukan secara bertahap oleh panitiapelaksana program kerja, koordinatordesa, coordinator lapangan, kepala desa dan Dosen Pembimbing Lapangan (DPL) secara bertahap untuk mengetahui apa yang menjadi hambatan dan hal-hal yang belum maksimal selama program berlangsung.

\section{KESIMPULAN}

Program Kuliah Kerja Sibermas (KKS) Pengabdian dengan tema "Pemberdayaan masyarakat melalui pembentukan kelompok Warga Perduli Aids (WPA) berbasis kearifan local di Desa Leboto Kecamatan Kwandang Kabupaten Gorontalo Utara Provinsi Gorontalo." yang dilaksanakan dengan menerjunkan mahasiswa untuk melakukan pendampingan kepada pihak pemerintah desa dan masyarakat terlebih khusus bagi remaja, yang bermanfaat dalam menangani masalah- 
masalah yang dimiliki oleh remaja.

\section{Kegiatatan}

diawali

dengan sosialisasi di sekolah sekolah yang ada di desa leboto yang kemudian dilanjutkan dengan pengkaderan warga peduli Aids (WPA). Selain itu, dilaksanakan kegiatan tambahan yaitu Turnamen takraw dan pentas seni yang bekerjasama dengan Rema Muda desa Leboto.

UCAPAN TERIMA KASIH

Sebagai penyusun saya berterima kasih kepada semua pihak yang telah berpartipasi dalam kegiatan ini, khususnya masyarakat Desa Leboto serta pihak sekolah yaitu Sma Miftahul Huda \& Smk Kesehatan Muhammadiyah yang member izin dan turut membantu pelaksanaan pengabdian kepada masyarakat ini.

\section{REFERENCES}

1. Irwan. Kearifan Lokal dalam Pencegahan HIV/AIDS pada Remaja Beresiko Tinggi. In: Absolute Media: Yogyakarta. 2018.

2. Irwan. Risiko Penularan HIV/AIDS pada Pekerja Seks Komersial (PSK) di Provinsi Gorontalo. J Heal Sci Gorontalo J Heal Sci Community. 2018;2(2).

3. Irwan, Nule R. Hubungan Dukungan Sosial Dengan Perilaku Merokok Pada Siswa Smk N 2 Limboto. J Heal Sci Gorontalo J Heal Sci Community. 2018;3(1).

4. Green L, Kreuter M. Health promoting palnning: an educational and environmental approach. In: California: Mayfield Publishing Co. 2010. p. 35-46. 
5. Herek G, Capitanio J,

Ethics

W Inter.

Widaman K. HIV-related 2012;30(4).

stigma and knowledge in the United States: prevalence and trends,. Am J Public Heal.

9. Kusmiran E. Kesehatan Reproduksi Remaja dan Wanita. In: Salemba Medika: Jakarta. 2013. 2012;92(3):371-7.

6. Maughan-Brown B. Attitudes towards people with HIV/ AIDS: Stigma and its determinants amongst young adults in Cape Town, South Africa. In: South African Rev Sociol. 2011.

7. Septiani N, Wulandari F. Pengetahuan Remaja Tentang HIV/AIDS

Dengan Pencegahan HIV/AIDS Di SMA Negeri 10 Purworejo Kabupaten Purworejo. J Komun Kesehat. 2016;7(1).

8. Herek G. Thinking about AIDS and stigma: A psychologist's perspective. J Law Med 